\title{
Community- vs. healthcare-associated Clostridium difficile infections, Finland, 2008-2013: incidence, case fatality and genotypes
}

\author{
SM Kotila, S Mentula, J Ollgren, A Virolainen-Julkunen, O Lyytikäinen* \\ From 3rd International Conference on Prevention and Infection Control (ICPIC 2015) \\ Geneva, Switzerland. 16-19 June 2015
}

\section{Introduction}

Clostridium difficile is not restricted to acute care hospitals.

\section{Objectives}

The objective was to evaluate the incidence, case fatality and trends of community- (CA) vs. healthcare-associated (HA) C. difficile infections (CDI) in Finland during 20082013.

\section{Methods}

CDI cases were identified from the National Infectious Disease Register to which all microbiology laboratories have notified toxin-positive $C$. difficile findings since 2008. Using cases' national identity codes, dates of death were obtained from the National Population Information System and data of the National Hospital Discharge Register was used to classify cases as CA or HA. PCR ribotyping results were obtained from the reference laboratory.

\section{Results}

A total of 33,303 CDI cases were identified; 10,874 (32.7\%) were CA $(33.7 / 100,000)$. The average annualised incidence rate of CA-CDI was significantly higher among persons aged 0-44 years, whereas in older age groups HA-CDI rates were higher. CA-CDI rate was higher in females than in males, especially in persons aged 15-44 years. The overall annual incidence rate of CDI decreased significantly, from $120.0 / 100,000$ in 2008 to 93.4 in 2013, related to the decreasing rate of HA-CDI. 30-day case fatality was lower in CA-CDI than in HA-CDI in all age groups. Altogether 1211 C. difficile isolates were linked

National Institute for Health and Welfare, Helsinki, Finland with CDI cases (3.6\%), of which 268 were CA and $943 \mathrm{HA}$. In both groups the most frequent PCR ribotype was 027.

\section{Conclusion}

While HA-CDI rate decreased, likely in response to improved infection control and increased awareness, CA-CDI rate remained stable. Preventive efforts, such as antimicrobial stewardship campaigns, should also cover long-term care and out-patient settings.

\section{Disclosure of interest}

None declared.

Published: 16 June 2015

doi:10.1186/2047-2994-4-S1-P23

Cite this article as: Kotila et al:: Community- vs. healthcare-associated Clostridium difficile infections, Finland, 2008-2013: incidence, case

fatality and genotypes. Antimicrobial Resistance and Infection Control 2015 4(Suppl 1):P23.

Submit your next manuscript to BioMed Central and take full advantage of:

- Convenient online submission

- Thorough peer review

- No space constraints or color figure charges

- Immediate publication on acceptance

- Inclusion in PubMed, CAS, Scopus and Google Scholar

- Research which is freely available for redistribution 